\title{
How do Shop Stewards Perceive their Situation and Tasks?: Preconditions for Support of Union Work
}

Sofie Pilemalm, Niklas Hallberg and Toomas Timpka

\author{
Linköping University Post Print
}

\section{Tweet}

N.B.: When citing this work, cite the original article.

Original Publication:

Sofie Pilemalm, Niklas Hallberg and Toomas Timpka, How do Shop Stewards Perceive their Situation and Tasks?: Preconditions for Support of Union Work, 2001, Economic and Industrial Democracy, (22), 4, 569-599.

http://dx.doi.org/10.1177/0143831X01224006

Copyright: Sage

Postprint available at: Linköping University Electronic Press http://urn.kb.se/resolve?urn=urn:nbn:se:liu:diva-13485 


\title{
Paper II:
}

\section{How do Shop Stewards Perceive their Situation and Tasks? Preconditions for Support of Union Work}

\author{
Sofie Pilemalm, Niklas Hallberg, and Toomas Timpka
}

Published in: Economic and Industrial Democracy, Vol. 22, Iss. 4, pp. 569-599.

\begin{abstract}
When unions world-wide confront a decline in density and power, pressure increases on shop stewards. They occupy a position which has been described as demanding, involving striking a balance between conciliation and tough negotiating, between ordinary and union work, and feelings of isolation from members. If shop stewards already experience a demanding work situation, and parallel to this the overall union conditions become aggravated, a next step would be to find out in what ways their situation can be facilitated. This article is based on data describing recent experiences of Swedish shop stewards, and it compares their situation to that described in the international research literature. It is found that the basic components of union work remain stable, in spite of recent labour relation changes and national differences. However, less than half of the reported problems were related to the direct contact with the employer. Shop stewards generally experience a situation characterised by inherent conflicts and wide-ranging tasks, resulting in high demands on their skills and in role overload. On the other hand, the results indicate differences with regard to union affiliate, age, experience and gender. In the eyes of union members the shop stewards largely embody the union organisation. Therefore, they should receive increased attention when dealing with the problems of unions. Measures to facilitate their work can include training, supportive networks and access to adequate information technology, and can further be targeted with regard to age/experience and gender.
\end{abstract}

\section{Keywords}

labour relations, trade unions, shop stewards, union membership 
How do Shop Stewards Perceive their Situation and Tasks?

Preconditions for Support of Union Work 


\section{Introduction}

Over the past decades, the political, economic and social roles of labour unions have changed dramatically in western countries (Bognanno and Kleiner, 1992). As a consequence of changed industrial relations and employer strategies, in some countries in combination with anti-union legislation, union movements world-wide face increasing challenges as regards decline in density and power (Addison, 1998; Reynolds, 1998). In addition, unions have to be committed to ever increasing demands on organisational effectiveness. This has necessitated new union strategies and long-term planning (Sandberg et al, 1992; Clark et al, 1998). In Sweden, The Swedish Trade Union Confederation (LO) organises approximately two million blue-collar workers and is thereby the largest national union organisation. The Swedish Confederation of Professional Employees (TCO) and The Swedish Confederation of Professional Associations (SACO) organise white-collar workers and academics respectively. They are all umbrella organisations with marked centralised structures, consisting of individual affiliates and several hierarchic levels. However, in recent years, the affiliates and the local level have gained substantial of power and may threaten the centralisation. While SACO has traditionally had a rather collaborative relation with the employers' associations, LO and TCO have been conflict oriented. LO has traditionally held a strong position, both in an international perspective and compared to TCO and SACO. The unionised part of the workforce has exceeded $80 \%$, and the organisation's activities have had an emphasis on collective bargaining. In Sweden, a long tradition of political-union co-operation has resulted in extensive laws and agreements regulating the rights of workers. One of the most important is perhaps the Representative Act that was established in 1973. The law acknowledges that shop stewards have the right to take leave from ordinary work to perform their union tasks, on time paid by the employer, and that they also have the right to training. This law and others ${ }^{1}$ has made it possible for shop stewards to take part in management boards, and carry out their role openly and actively at the workplace (Sandberg et al, 1992). It has thereby provided them with the ability to affect not only issues concerning salary and working time, but also those concerning conditions, technology and co-determination (Ehn and Kyng, 1987). Comparatively low unemployment rates have further favoured the LO unions. However, LO too has experienced substantial pressure on its role due to recent developments, which include a cut in state resources, the increase of market economy forces and new management strategies comprising individual setting of wages and profit sharing (Sandberg et al, 1992). Even if overall union density has not decreased

\footnotetext{
${ }^{1}$ For instance the Co-determination Act of 1976. See Sandberg et al, (1992) for a survey of this and similar laws and agreements.
} 
significantly it has fluctuated markedly, with young people and immigrants being those less inclined to unionise (Kjellberg, 2000).

\section{Increasing responsibilities for local shop stewards}

While unions as a whole experience increasing challenges, a corresponding strain is put on the local unions. While the upper levels have to deal with a fading membership and formulate new strategies, it is primarily the work situation at the local shop-floor level that is affected. This refers not the least to the shop stewards who have part time union assignments representing their colleagues at the work place. In Sweden, the total number of shop stewards is currently estimated to be approximately 225000 . The shop stewards play a central role within the union movement, as they most often constitute its contact with members and external actors. While the determinants of individual union membership have received a great deal of attention in scholarly research (Viswesvaran, 1998; Arye and Debrah, 1997; Kelly and Kelly, 1994), the same cannot be said of the potential influence of the shop stewards' work on these decisions. Nevertheless, shop stewards' efforts cannot be disregarded as being of little importance for members. Further, the last decades' rationalisations, where many organisations have been flattened and responsibility has moved downwards in the organisation, might well oblige the unions to follow suit. It has been claimed that the comparatively strong position of the Swedish union movement partly can be explained by its simultaneously centralised and decentralised structure, where the local workplace organisation carries out important union functions (Kjellberg, 1983). This development has been increasingly accentuated in recent years.

\section{Study aims}

The main aim of this study is to address the present situation of Swedish LO shop stewards, i.e., what tasks they are required to perform and what problems they experience. International comparisons will be made when possible. A second aim is to look at perceived differences among shop stewards with regard to union affiliate, age, experience and gender. Such comparisons are expected to provide useful information on how to support and improve union work quality. A third aim is to identify such national and institutional similarities and differences, for the purpose of targeting needs and support. 


\section{Shop stewards in international research literature}

In an international perspective, the typology of shop stewards has been a subject of interest. In 1977, Batstone et al published a comprehensive study of British shop stewards. It centred much on how different shop steward types affected relations and assignments at the workplace. They separated the leader type whose commitment was based on a fundamental belief in union principles, from the populist type who act more as delegate and protector of member interests. They further found that the former was more successful in forming member and steward networks, and in protecting members' interests. Later, Reshef (1987) performed a study among American shop stewards and distinguished between the co-operative, erratic, radical, passive and failed shop steward.

The actual work situation of shop stewards has thus far received little attention. However, Poole (1974) extracts major union duties among British shop stewards, e.g., representing the members alternatively the union organisation, active negotiating and protection of members, and active conciliation and dispute resolution. Fischer and Reshef (1992) further tried to identify what constraints Canadian shop stewards face in their day-to-day work. The findings included member apathy (76 percent of sample), the dual role of worker and shop steward (31 percent), complexity of collective agreements (30 percent), members' expectations (29 percent), management and supervisors' treatment (23 percent), lack of adequate training ( 22 percent), inability to satisfy both the union and management (15 percent), lack of authority to act (14 percent), lack of support by higher union officials (12 percent), members' criticism (12 percent), and steward role not clearly defined (10 percent).

Further, the relationship between shop stewards and union members has been looked into. Crain (1994) maintains that the work of shop stewards is of immediate importance for membership since they are the ones who organise and deal with the problems of members. Meanwhile, insufficient contact with members has been reported as the common problem from the perspective of shop stewards (Batstone et al, 1977). Another British study suggests that shop stewards talk to each other more frequently than with their members. In addition, misconception about union work and commitment exists among members who sometimes blame this on lack of training and communication skill on the part of shop stewards. In fact, this was also sometimes the case, since many shop stewards themselves expressed uncertainty about union structure and policy work (Schuller and Robertson, 1983).

The situation of shop stewards under changing circumstances has also been studied. Pupo and White (1994) studied the roles of union work in a Canadian 
setting. They claim that the basic assignments, e.g., negotiating and defending members' interests, have remained the same despite economic and workplace changes. Others have however reported changes. Darlington (1994) and Terry (1995), view the role and work of British shop stewards during changing circumstances in retrospect. They distinguish an overall decline in shop-steward militancy and power during the 1980's, resulting among other things in less involvement of local shop stewards in negotiating with management, and in an increased bureaucratic and detached tension in relationship with their members. It has further been argued in a Canadian study (Rheaume, 1998) that the last decades' changes in workplace structure have had an impact on union work conditions, with added pressure frequently resulting in distress. Rigby and Smith (1999) base their analysis on four European countries (Germany, Italy, Spain and the UK). When examining union responses to a hostile environment, they found that an oppositional relationship with the employer is increasingly being abandoned, and a recognition of the need to become responsive to membership in organisational and structural terms.

Most studies of shop stewards treat prevailing situations with no particular suggestions for their improvement. However, Terry (1995) has noted a perceived need for support in day-to-day union activities at the local level.

\section{Swedish shop stewards}

Swedish shop stewards have been said to enjoy an in various ways different situation to their peers in other countries. They have their belonging in a strong organisation and are backed up by laws and agreements regulating their rights to participate in union activities and promote membership at the workplace. This is to be compared with for instance the USA, France, Italy, and Spain, where the unions have a weak constitutional position, and experience difficulties to attract members. In the UK, the anti-union legislation from the 1980's has severely undermined the position of the unions, and in Germany, unions are not represented at the workplace. Instead, the workers are represented in work councils, representing their colleagues rather than the union organisation as such. Other countries, e.g., Holland and the Scandinavian countries, have a union structure more similar to the Swedish (Sandberg et al, 1992; Lecher, 1994). In Sweden, the aforementioned circumstances have provided shop stewards with an extensive sphere of action, but also with corresponding responsibilities, as many negotiations and other duties are performed at the local level.

However, Swedish shop stewards have been less focussed on in the research literature. The situation of ordinary and regional safety representatives has been 
examined (e.g., Frick, 2000; Frick and Walters, 1998; Walters and Frick 2000). The safety representatives occupy a low status position in union terms and are increasingly difficult to recruit. Frick (2000) performed an extensive study of their situation and knowledge support based on interviews with approximately 40 safety representatives from different branches, and a survey sent to all affiliates in LO, TCO, and SACO. He found that safety representatives occupy an exposed position with insufficient support to deal with short- and long- term changes on the labour market. It is argued that they need increased support and training, and that the problem is not so much access to information and knowledge, but to create possibilities for their learning and development of competence. Regional safety representatives occupy a somewhat different position since the unions often employ them full-time. But also they experience difficulties in their assignment. Frick and Walters (1998) and Walters and Frick (2000) based their study on a survey sent to the total population of $1500 \mathrm{LO}$ and 100 TCO safety representatives. They found that safety representatives often find it hard to balance multiple roles, and their support and training is deemed to be insufficient.

But safety representatives constitute only approximately 25 percent of the total force of LO shop stewards (60 000 of 240000 ). Meanwhile, research has shown that union commitment in Sweden is increasingly based on instrumental grounds, which result in non-active members. Sverke and Sjöberg (1997) studied membership in three LO affiliates and found instrumental membership to be dominating over ideological. They conclude that unions must head in new directions in order to enhance active participation. Further, Kjellberg (1998) investigated union fluctuation among LO members. He found that women, immigrants and young people are less inclined to unionise, and suggests that union renewal must be given high priority if new groups of members are to participate in unions.

\section{An empirical investigation of the situation of Swedish shop stewards}

The international research literature referred to describes the situation of shop stewards as exacting, involving multiple roles, and frequently experiencing insufficient contact with indifferent members. Because the presence of capable shop stewards is crucial to unions, they have to be in focus when confronting contemporary challenges and if necessary, measures should be taken to support their work. Yet, studies tend to address attitudes to existing situations, neglecting discussions about their potential improvement. One would expect Swedish shop stewards to be proportionally well-resourced and perhaps experiencing their duties as less demanding, due to LO's strong position and extensive regulations guaranteeing their rights. On the other hand it is possible 
that they experience extensive demands, since the local workplace level here shares a large part of the responsibility for carrying out union functions. It seems that an overall investigation of the situation and tasks of Swedish shop stewards is absent. It is also worth mentioning that all the studies described are of a quantitative character with no self-report of how shop stewards perceive their situation. A survey of their work situation and how it can be improved therefore seems imperative.

\section{Methods and materials}

The investigation was based on a qualitative analysis complemented with quantitative data to provide an approximate distribution of identified union work situations, with regard to categories and institutional variances. Drawing on a questionnaire sent to a sample of shop stewards, problems experienced in dayto-day union work were categorised and used as a basis for suggesting the fundamental components of shop stewards' work situation and how it can be improved.

\section{Study group}

The shop stewards were randomly sampled from six union affiliates - Metal Workers $(N=81,21$ percent of sample), Construction Workers $(N=69,18$ percent), Transport Workers $(N=74,19$ percent $)$, Trade Workers $(N=49,13$ percent), Paper Workers ( $N=52,13$ percent), and Municipal Workers $(N=61,16$ percent). The unions were asked to provide addresses to a representative sample of shop stewards with regard to gender, age, and experience. Thus, the sample is intended to reflect the affiliates' characteristics, but does not include demands for exact distribution among affiliates and different groups of shop stewards. The study group was guaranteed anonymity and was not informed about the motives behind the questionnaire. ${ }^{2}$

\footnotetext{
${ }^{2}$ The reason for the latter was that parts of the questionnaire were to be used for the purpose of identifying needs for information technology among shop stewards, and it was desirable that the respondents were not restricted by thinking directly in terms of technology. The study was undertaken within the framework of the DLK-project (Distance education for Local Knowledge needs). It is a project where shop stewards, teachers from a union folk highschool (these are schools run by the LO that are open to their members and especially for those with union assignments - both union and more general courses are taught there) and researchers from Linköping University work together to study how information technology can be used to facilitate the day-to-day matters of shop stewards.
} 


\section{The Critical incident technique - its background and application}

For the collection and categorisation of data, the Critical incident technique was used. The original focus of the technique is on human behaviour observed in recurrent critical situations. The critical incidents can then be used to form the basis for change of work routines (Flanagan, 1954). The technique provides principles for categorisation of incidents which have continually been developed and refined (Bradley, 1992). Initially, a frame of reference that is related to the object of the investigation should be established. In the subsequent data analysis, incidents are usually clustered together with similar incidents and formulated into tentative categories. Additional incidents are then tested against them. Tentative categories can be changed and new ones added, until the modified or final categorisation is decided upon.

The Critical incident technique emerged as a method during the 1940's and 1950 's (Flanagan, 1954). It was soon adopted by work psychologists, initially by Herzberg who studied factors leading to high level of satisfaction respectively dissatisfaction among middle management personnel (Gardell and Westlander, 1968). The Critical incident technique has since been developed and applied in different disciplines, e.g., in management science and the caring sciences (Dean, 1998; Norman et al, 1992; Cheek et al, 1997). It has however also been criticised. It has for instance been questioned whether the observed factors really are representative of the whole attitudinal variation of the respondents. Also, the mere occurrence of critical incidents reveals nothing about their frequency, and respondents may have difficulty in reconstructing their own historical incidents (Hultaker, 1977). On the other hand, it has been argued that the results from studies applying Herzberg's technique have been significantly unanimous and also in line with studies using other approaches for studying the same phenomena, e.g., questionnaire based attitude studies and linear models of job satisfaction (Hultåker, 1977).

In this study, the Critical incident technique was used as a means to discern what problems shop stewards are faced with in day-to-day union work. The technique was developed to include the use of questionnaires. A questionnaire was sent to a sample of 386 shop stewards. The respondents were asked to:

1. Give a description of the most recent problem they had experienced in their union work;

2. describe what consequences the problem had had for them;

Before considering information technology solutions, knowledge about shop stewards' situation and tasks is essential. The result of the second part of the questionnaire is described in Pilemalm et al 2001. 
3. describe how they had handled the situation;

4. tell if they could think of something that could prevent or solve the problem in the future;

5. estimate how often the problem occurred.

Even if the approach of using questionnaires does not overcome potential objections to the method as regards representativity of incidents and respondents' reconstruction of reality, it reaches a larger sample of respondents. It is thereby easier to control uniformity of results and the frequency of incidents.

\section{Empirical material}

Of the 386 questionnaires, 248 were returned, corresponding to a response rate of 64 percent. $^{3}$ Of the returned questionnaires, 36 contained no problem description or the respondents had explicitly stated that they had not experienced any problems within their area of commitment. This relatively high dropout rate may be explained with that shop stewards mostly work with problems, i.e., when something causes breakdowns at the workplace. They may therefore have had experienced difficulties in relating to the questionnaire - if they were supposed to describe day-to-day tasks or problems besides them. Further, it was not possible to categorise nine responses since the respondent had not reported a problem but something else, or the answer provided was unintelligible. However, those shop stewards who had responded did experience problematic situations within their union work (Table 1).

Table 1. Participants in relation to core problem report (in numbers).

\begin{tabular}{lllll}
\hline Study sample & Respondents & $\begin{array}{l}\text { No problem } \\
\text { report }\end{array}$ & N/A $\mathrm{A}^{\mathrm{a}}$ & $\begin{array}{l}\text { Respondents who } \\
\text { reported core problems }\end{array}$ \\
\hline 386 & 246 & 36 & 9 & 201 \\
\hline
\end{tabular}

\section{Data analysis}

In the data analysis, problems were categorised with respect to what constituted the core problem, namely what was interpreted as the major problem, also in cases where smaller sub-problems could be discerned within the problem

\footnotetext{
${ }^{3}$ When looking at the individual affiliates, the response rate was 68 percent for Metal Workers, 74 perecent for Construction Workers, 68 percent for Transport Workers, 71 percent for Trade Workers, 62 percent for Paper Workers, and 43 percent for the Municipal Workers' union.
} 
description. Further, the relations between categories were examined to further inform an overall comprehension of union activities. ${ }^{4}$ In most cases, the respondents had explicitly stated what they saw as the core problem themselves. Sometimes, the problem descriptions were vague, however, and the researchers had to filter out the core problems. The categorisation showed that the problems experienced by shop stewards were related for the most part to the other social actors involved in workplace democracy, i.e., shop steward-employer problems (44 percent), shop steward-member problems (30 percent), personal problems (13 percent) and shop steward-union problems ( 9 percent). A fifth small category concerned the shortage of work prevalent in Sweden, resulting in companies being forced to cut back. This was described as a problem concerning national economy over which employers and unions have little influence. Within the categories, problems could be discerned to appear within the union assignment as such, but a substantial proportion of the problems also took place on a more personal level, i.e., they fell outside standard union tasks. Also, in the member and union issue categories, a considerable proportion of the problems concerned a general lack of commitment or suspicion as regards union questions on behalf of the other party. Hence, a number of sub-categories could be formed within the major categories.

\section{Findings}

When investigating the frequency of core problem categories among and between union affiliates, gender, age groups and experience, the following differences were found (see Table 2.). Experience refers to how many years the respondent has had his or her union assignment.

\section{Problems related to employers}

Most of the problems experienced in the day-to-day union work involved the employer. The typical situation involved a male shop steward in the Transport Workers' union. Here, over half of the reported problems were related to the employer. In overall, male respondents showed a comparatively higher tendency to report employer problems. Also the age group 56+ reported more than average as regards the employer category. On the other hand, those with more

\footnotetext{
${ }^{4}$ Two researchers independently undertook the categorisation and then compared their results. In addition, an external researcher, not involved in the project, scrutinised the categories, to reduce risks of subjective elements intruding in the categorisation. Even if some overlapping of categories is inevitable, e.g., some problems can be attributed to more than one category, they have been categorised with reference to what constitutes the core problem.
} 
than 20 years experience of union work reported less than average. The problems basically concerned traditional union tasks such as negotiations, interpretation of agreements and other disputes in which the parts had different interests. A typical dilemma could be:

After the company went bankrupt and was to be restarted, the owner (there was only one owner by that time) tried to skip three men in the priority list, at the time of reemployment. ${ }^{5}$

However, a substantial part of the problems can be classified as belonging outside ordinary union tasks. These were considered as relational problems where the shop stewards felt continually counteracted or even harassed by the employer. The shop stewards often felt attacked as individuals, rather than in their role as shop stewards:

The latest problem is that we are continually being harassed by and subjected to mental stress by the employer. The company has tried to buy out my right of priority, maligned me, told me that I am not eligible at the company because 'I do a worthless job and the local managers do not want me in the team'. This is only because I work actively with union issues within the company. The company has a hostile attitude towards the union.

\section{Problems related to members}

Problems as related to members made up the second largest category. The typical incident involved a female shop steward in the Municipality Workers' union. Here, half of the respondents' reported problems related to member work. In general, female respondents were more strongly represented in the member problem category. As considers age, the group 56+ reported few problems related to members. On the other hand, those with more than 20 years of experience reported more than average. In this category, most often a member had a problem which the shop stewards were expected to solve, or were related to the shop stewards' duties to inform about and explain agreements and other settlements with the employer. This often involved conflicting perspectives:

\footnotetext{
${ }^{5}$ The following quotations are directly translated from the questionnaires. Hence, comments in parentheses and quotation marks appear as in the original statements.
} 
How do Shop Stewards Perceive their Situation and Tasks?

Preconditions for Support of Union Work

Table 2. Core problem distribution among and between core problem categories, union affiliates, gender, age and experience in percentages and with 95 percent confidence intervals within brackets.

\begin{tabular}{|c|c|c|c|c|c|}
\hline Union affiliate & $\begin{array}{l}\text { Shop } \\
\text { steward - } \\
\text { employer }\end{array}$ & $\begin{array}{l}\text { Shop steward- } \\
\text { members }\end{array}$ & $\begin{array}{l}\text { Shop steward- } \\
\text { union }\end{array}$ & Personal & $\begin{array}{l}\text { Shortage } \\
\text { of work }\end{array}$ \\
\hline All $(\mathrm{N}=201)$ & \begin{tabular}{|l|}
$44 \%$ \\
$(37-51 \%)$ \\
\end{tabular} & $\begin{array}{l}30 \% \\
(24-36 \%)\end{array}$ & \begin{tabular}{|l}
$9 \%$ \\
$(5-13 \%)$ \\
\end{tabular} & \begin{tabular}{|l|}
$13 \%$ \\
$(8-18 \%)$ \\
\end{tabular} & \begin{tabular}{|l|}
$4 \%$ \\
- \\
\end{tabular} \\
\hline $\begin{array}{l}\text { Metal } \\
\text { Workers (46) }\end{array}$ & $\begin{array}{l}46 \% \\
(31-60 \%)\end{array}$ & $\begin{array}{l}26 \% \\
(13-39 \%)\end{array}$ & $\begin{array}{l}11 \% \\
(2-20 \%)\end{array}$ & $\begin{array}{l}15 \% \\
(5-26 \%)\end{array}$ & $\begin{array}{l}2 \% \\
-\end{array}$ \\
\hline $\begin{array}{l}\text { Construction } \\
\text { Workers (40) }\end{array}$ & \begin{tabular}{|l}
$40 \%$ \\
$(25-55 \%)$
\end{tabular} & $\begin{array}{l}30 \% \\
(16-44 \%)\end{array}$ & $\begin{array}{l}12 \% \\
(1-21 \%)\end{array}$ & \begin{tabular}{|l|}
$10 \%$ \\
$(2-20 \%)$
\end{tabular} & \begin{tabular}{|l|}
$8 \%$ \\
-
\end{tabular} \\
\hline $\begin{array}{l}\text { Transport } \\
\text { Workers (36) }\end{array}$ & $\begin{array}{l}55 \% \\
(39-72 \%)\end{array}$ & $\begin{array}{l}28 \% \\
(13-42 \%)\end{array}$ & $\begin{array}{l}3 \% \\
(0-10 \%)\end{array}$ & $\begin{array}{l}11 \% \\
(0-21 \%)\end{array}$ & $\begin{array}{l}3 \% \\
- \\
\end{array}$ \\
\hline $\begin{array}{l}\text { Trade } \\
\text { Workers (29) }\end{array}$ & \begin{tabular}{|l|}
$45 \%$ \\
$(27-63 \%)$
\end{tabular} & $\begin{array}{l}28 \% \\
(11-44 \%)\end{array}$ & \begin{tabular}{|l}
$10 \%$ \\
$(0-21 \%)$
\end{tabular} & \begin{tabular}{|l}
$10 \%$ \\
$(0-21 \%)$
\end{tabular} & \begin{tabular}{|l|}
$7 \%$ \\
-
\end{tabular} \\
\hline $\begin{array}{l}\text { Paper } \\
\text { Workers (27) }\end{array}$ & $\begin{array}{l}45 \% \\
(25-63 \%)\end{array}$ & $\begin{array}{l}22 \% \\
(7-38 \%)\end{array}$ & $\begin{array}{l}7 \% \\
(0-17 \%)\end{array}$ & $\begin{array}{l}22 \% \\
(7-38 \%)\end{array}$ & $\begin{array}{l}\% \\
-\end{array}$ \\
\hline $\begin{array}{l}\text { Municipal } \\
\text { Workers (22) }\end{array}$ & \begin{tabular}{|l|}
$27 \%$ \\
$(9-46)$ \\
\end{tabular} & $\begin{array}{l}50 \% \\
(29-70 \%) \\
\end{array}$ & \begin{tabular}{|l|}
$14 \%$ \\
$(0-28 \%)$ \\
\end{tabular} & \begin{tabular}{|l|}
$9 \%$ \\
$(0-21 \%)$ \\
\end{tabular} & - \\
\hline Not available (1) & - & 1 & - & - & . \\
\hline \multicolumn{6}{|l|}{ Gender $(\mathrm{N}=201)$} \\
\hline Male (146) & \begin{tabular}{|l|}
$49 \%$ \\
$(42-56 \%)$
\end{tabular} & $\begin{array}{l}27 \% \\
(21-33 \%) \\
\end{array}$ & \begin{tabular}{|l|}
$7 \%$ \\
$(3-11 \%)$ \\
\end{tabular} & \begin{tabular}{|l|}
$12 \%$ \\
$(6-17 \%)$ \\
\end{tabular} & $5 \%$ \\
\hline Female (50) & $\begin{array}{l}32 \% \\
(19-45 \%)\end{array}$ & $\begin{array}{l}36 \% \\
(23-49 \%)\end{array}$ & $\begin{array}{l}14 \% \\
(4-24 \%)\end{array}$ & $\begin{array}{l}18 \% \\
(7-29 \%)\end{array}$ & - \\
\hline Not available (1) & - & 3 & 2 & - & - \\
\hline \multicolumn{6}{|l|}{ Age $(\mathrm{N}=201)$} \\
\hline $16-35(53)$ & $\begin{array}{l}38 \% \\
(25-51 \%) \\
\end{array}$ & $\begin{array}{l}28 \% \\
(16-40 \%)\end{array}$ & $\begin{array}{l}13 \% \\
(4-22 \%)\end{array}$ & \begin{tabular}{|l|}
$19 \%$ \\
$(8-29 \%)$
\end{tabular} & \begin{tabular}{|l|}
$2 \%$ \\
- \\
\end{tabular} \\
\hline $36-45(66)$ & $\begin{array}{l}48 \% \\
(37-61 \%)\end{array}$ & $\begin{array}{l}27 \% \\
(17-38 \%)\end{array}$ & $\begin{array}{l}8 \% \\
(1-14 \%)\end{array}$ & $\begin{array}{l}12 \% \\
(4-20 \%)\end{array}$ & $\begin{array}{l}5 \% \\
- \\
\end{array}$ \\
\hline $46-55(61)$ & $\begin{array}{l}41 \% \\
(29-53 \%)\end{array}$ & $\begin{array}{l}38 \% \\
(26-50 \%)\end{array}$ & $\begin{array}{l}10 \% \\
(2-17 \%)\end{array}$ & $\begin{array}{l}8 \% \\
(1-15 \%)\end{array}$ & $\begin{array}{l}\% \\
-\end{array}$ \\
\hline $56+(20)$ & \begin{tabular}{|l|}
$55 \%$ \\
- \\
\end{tabular} & $\begin{array}{l}20 \% \\
- \\
\end{array}$ & - & \begin{tabular}{|l|}
$15 \%$ \\
-
\end{tabular} & \begin{tabular}{|l|}
$10 \%$ \\
- \\
\end{tabular} \\
\hline Not available (1) & - & - & 1 & - & - \\
\hline \multicolumn{6}{|c|}{ Experience $(n=201)$} \\
\hline $0-5(62)$ & \begin{tabular}{|l|}
$47 \%$ \\
$(34-59 \%)$ \\
\end{tabular} & $\begin{array}{l}29 \% \\
(18-40 \%)\end{array}$ & $\begin{array}{l}6 \% \\
(0-13 \%) \\
\end{array}$ & \begin{tabular}{|l|}
$16 \%$ \\
$(7-25 \%)$ \\
\end{tabular} & $\begin{array}{l}2 \% \\
- \\
\end{array}$ \\
\hline $6-10(56)$ & $\begin{array}{l}46 \% \\
(33-59 \%)\end{array}$ & $\begin{array}{l}21 \% \\
(12-30 \%)\end{array}$ & $\begin{array}{l}13 \% \\
(4-21 \%)\end{array}$ & $\begin{array}{l}16 \% \\
(6-26 \%)\end{array}$ & $\begin{array}{l}4 \% \\
- \\
\end{array}$ \\
\hline $11-20(62)$ & \begin{tabular}{|l|}
$42 \%$ \\
$(30-54 \%)$
\end{tabular} & $\begin{array}{l}32 \% \\
(21-44 \%)\end{array}$ & $\begin{array}{l}11 \% \\
(3-19 \%)\end{array}$ & \begin{tabular}{|l|}
$10 \%$ \\
$(2-17 \%)$
\end{tabular} & $\begin{array}{l}5 \% \\
- \\
\end{array}$ \\
\hline $20+(21)$ & \begin{tabular}{|l|}
$33 \%$ \\
$(13-53 \%)$
\end{tabular} & $\begin{array}{l}48 \% \\
(21-75 \%)\end{array}$ & $\begin{array}{l}5 \% \\
-\end{array}$ & \begin{tabular}{|l|}
$5 \%$ \\
-
\end{tabular} & \begin{tabular}{|l|}
$9 \%$ \\
-
\end{tabular} \\
\hline
\end{tabular}


We have a payment system that is built around different matrices, which can generate more money if we do the right things. We work in different departments with separate systems, which means that we earn different amounts each month. (The matrix makes up for about 25 percent of the salary). Unfortunately, for a couple of months the amounts have differentiated substantially between the departments (about 12 SEK per hour) ${ }^{6}$, which has created conflicts and certain envy. Some have a hard time accepting that others want to do the right things that they gain from. One has to create the true picture of the phenomena.

However, also with reference to members, relational problems outside ordinary union tasks were substantial. Many shop stewards felt constantly counteracted and attacked because of their union commitment. Members reacted with jealousy and distrust when the shop stewards had to be absent from work, or they questioned the competence of the latter. Further, the shop stewards felt that they often were personally attacked because of union decisions in which they had no saying. A problem could be:

Being attacked for being involved in the union out of own interests, i e., carrier and receiving benefits. Having to defend the fact that that there are certain morons who take advantage of their positions within the movement.

As to members, another dilemma concerned their lack of commitment to union questions and their distrust as regards the movement in general. This problem demanded great effort from the shop stewards as to informing, explaining and arguing:

To elucidate or explain 'the role of the union' in society. Partially to the individual, why he/she should join the union. That the union is no institution/authority and that the union is not an enemy of the employer but a collaboration partner. But who still works for improving the living conditions, work conditions, work environment etc. of members.

\section{Problems related to the union organisation}

Problems reported by the shop stewards were also associated with the union organisation itself, from local branch to central level. Female respondents were more strongly represented than were male respondents. At the union work level, shop stewards experienced structural problems within the organisation that rendered their tasks more difficult to accomplish. For instance, they did not receive necessary information in time:

\footnotetext{
${ }^{6} 12$ SEK is about US\$ 1.5.
} 
Within the union we have no access to information on wage negotiations in progress, but have to rely on the mass media.

Outside ordinary union tasks, relation problems as regards the shop stewards and their union environment were a problem. At times the shop stewards felt counteracted by the local union branch or had problems co-operating with other shop stewards:

When I as vice chairperson take over when the ordinary chairperson is absent and do not know where papers are or what has previously been said, and other board members have but do not release the information needed, in order to put me in an unfavourable light and make themselves stars.

Also at the union level the commitment of others was sometimes seen as a problem. The shop stewards felt that their fellow shop stewards or higher levels within the union were not as committed to the assignment as they were - which rendered their tasks more difficult and affected enthusiasm:

The development within our union. As the union educational level in 'my' local branch is low on members as well as shop stewards, the development within the club has degenerated. The board lacks a firm ground for its work and members feel alienated from the union. The board does not attempt to solve the problem.

\section{Problems at the personal level}

A fourth category concerned problems experienced at a personal level, i.e., problems related to the shop stewards themselves, with no other part necessarily involved. The Paper Workers' union reported a comparatively high proportion of personal problems. Further, female respondents showed inclination to report in this category. As regards age, the age group 16-35 showed a higher tendency to report problems at the personal level. As to experience, the pattern was similar with higher representation of the groups with less experience. In the shop stewards' day-to-day work, the problems were described as insecurity and insufficiency in union commitment, often related to the feeling of a lack of knowledge. The shop stewards felt that they did not have enough knowledge or competence to deal with member questions, problems and other tasks:

Insecurity. It is easy to lose track when being 'confronted', especially if there is an issue I have not worked with, and also (especially now) as regards political discussions. 
However, problems related to the individual representative could also transcend the distinction between union tasks and private life. This took place when the shop stewards brought problems home, and their heavy union load of tasks came into conflict with spare time and family life:

During my time as chairperson, I had difficulties in relaxing from work when at home. If it was individual problems, it was hard. You carried the problems with you 24 hours-a-day. It was difficult to sleep, phone calls at nights, you want so much you become vulnerable yourself. Much travel within the union at group level. I am no longer a shop steward at my workplace.

\section{Shortage of work}

Lay-offs and shortage of work concerned a fifth, minor category. The problems had their origin in union tasks, but they also transcended the task level as not much could be done to reduce them. Instead, they tended to be connected to feelings of hopelessness and distress:

The situation of the construction trade is as black as night. There are no jobs. What I experience most as a shop steward is the resignation of members, but even more the [union] department. Shop stewards who have locked themselves in and no longer want to or are able to find solutions.

\section{General tendencies}

Female-respondents reported half of the relational problems in all categories, even though they only made up for one fourth of the total sample. Further, even though this is not displayed in the table, it is notable that the age groups 46-55 and 56+ indicated a higher tendency (one-fifth and one-third as compared to one-seventh overall) to reject problems.

\section{Complexity of core problems and long-term consequences}

In the main, the analysis revealed a complex problem picture where core problems were related to long-term consequences in vicious circles. In 58 percent of the situations, a core problem was associated with another (one or occasionally more than one) problem or consequence (Table 3.). Often, the secondary problems concerned impaired relations between the shop stewards and their environment, mostly between the employer and shop stewards, but even when members blamed the shop stewards for not being able to solve their dilemma or when work place relations as a whole were affected. Also, core problems led to members mistrusting or ignoring their union organisation. 
Above all, the secondary consequences occurred at an emotional level as primary problems of material nature caused dissatisfaction or mental suffering. In the former case, shop stewards had feelings of insufficiency, anger, discomfort or powerlessness in relation to the problems. In the latter case, the problems brought substantial mental distress with them, resulting in worries, stress, difficulty sleeping and sick leave. Further, problems often tended to be connected to shop stewards having to devote substantially more time than had been set aside for union tasks, or even experiencing the pure lack of time and resources.

Table 3. Secondary problems and consequences related to the subjects' core problem. Figures indicating the percentage of core problems associated with respective secondary problems.

\begin{tabular}{llllll}
\hline $\begin{array}{l}\text { Impaired } \\
\text { relations }\end{array}$ & $\begin{array}{l}\text { Mistrust/lack of } \\
\text { commitment }\end{array}$ & Dissatisfaction & $\begin{array}{l}\text { Mental } \\
\text { anxiety }\end{array}$ & $\begin{array}{l}\text { Time } \\
\text { pressure }\end{array}$ & None \\
\hline $14 \%$ & $6 \%$ & $15 \%$ & $11 \%$ & $13 \%$ & $42 \%$ \\
\hline
\end{tabular}

Detailed categorisation suggested that there were associations between certain core problem categories and secondary problems and consequences. Mental anxiety was manifest as a consequence of problems transcending union tasks and/or taking place at the relational level. Impaired relations, in their turn, occurred as result of dilemmas evolving within union tasks. For instance, in the largest core problem category of disputes between employer and shop stewards, almost one-third of problems resulted in deteriorated relations. Also, time pressure and experienced lack of resources were, not surprisingly, mainly consequences of problems occurring within union tasks. However, both union task and relational problems led to members discrediting their union organisation. The same applied to dissatisfaction. The main reason for shop stewards' dissatisfaction was, however, an overall pressing work situation with a lack of knowledge. Finally, an inflexible union organisation was sometimes described as aggravating these problem situations further. 


\section{Interpretation of the findings}

Drawing on previous studies and the preceding results, the shop stewards' perception of their union work can be described as involving several duties and having to perform a wide range of tasks. Important duties of the shop stewards where problems occur are as follows:

Formal negotiations: They represent the members in negotiations and other settlements with the employer. Tasks include reading and interpreting laws and agreements, planning and strategic thinking.

Being an informant: They inform members and employers about workplace related events, rights and duties of the parties and about the union organisation and ideology.

Arguing for union values: Shop stewards are often obliged to act as debaters and defenders of the union. They have to provide the information necessary to sustain their arguments, but desirable skills also include eloquence and the ability to argue.

Personal conflict management: Apart from formal disputes, shop stewards have to act as reconcilers in personal conflicts between members, and between members and employer. They are also often exposed to conflicts themselves. Of course, they are dependent on knowledge and the ability to argue to be able to solve the conflicts, but required skills also include mediation as well as insight and empathy.

Continuous knowledge acquisition: The shop stewards themselves have to acquire knowledge and support, most often from their own organisation, but also from external sources. Especially when acting on behalf of members, shop stewards are often dependent upon information to be able to solve their problems.

The specific union work environment appears to generate recurrent problem patterns. It has been acknowledged that in all occupations, the practitioners are sometimes exposed to conflicts (e.g., Gwartney-Gibbs, 1994). While this is the case, the conflict perspective in union tasks is inherent, constituting a major part of the assignment. Work conflict theory usually separates industrial conflicts related to disagreement over production issues between employer and workers, and social conflicts at workplaces, e.g., between internal friendship groupings (Edwards, 1992). Shop stewards continually play an active part in both these 
kinds of conflicts, in the former case as interested parties, in the latter case more as objective intercessors. Because their tasks often include conflict management at several levels, relations between the shop stewards and actors in their environment are intrinsic for the shop stewards' daily situation. Strained relations in turn often result in shop stewards experiencing dissatisfaction or even anxiety. This is further affected by a demanding load of tasks. Shop stewards frequently describe their tasks as time consuming and the union organisation as bureaucratically rigid or lacking in resources. This leads to inadequacy on the part of the shop stewards, which in turn is often noted by members who react with declining interest in the union. Furthermore, when members fall out with the shop stewards, they sometimes discredit the union as a whole. Thereby, the organisation does not receive the resources needed to improve, and a vicious circle arises that is difficult to break out of. The shop stewards' task-load is not reduced and a strained situation repeatedly results in dissatisfaction and sometimes in mental anxiety and conflicts with family life.

On the other hand, more detailed analysis points towards differences with reference to union affiliate, gender, age and experience. Above all, gender seems to have a significant impact on how union tasks were perceived. This may have several explanations. It can be that union tasks actually are gender related, i.e., male shop stewards more often act in negotiations and disputes with the employer while their female counterparts more often work with member contacts and questions. It is also plausible that female shop stewards experience difficulties in working in an organisation which is still dominated by men and a male culture, hence their higher representation in the relational and union organisation categories. Research has shown that persons who are a minority at the workplace more often are exposed to stress-inducing factors, related to conflict, assimilation and contrast (Kanter, 1977). In unions, it has been pointed out how female shop stewards in male dominated union offices feel less competent to participate in local activities than in those with a higher proportion of women (Mellor, 1995). With regard to the Swedish union organisation, the representation of females among union shop stewards is estimated to about $30 \%$, with variances as regards different affiliates. ${ }^{7}$ It may also have to do with gender differences in general. It has been for instance been shown how men and women attribute different qualities to themselves and how women feel less competent to deal with uncertainty (Clack, 1999). Further, Gwartney-Gibbs and Lach (1994) argue that female workers more often than their male counterparts tend to label conflicts taking place within their work as personal.

Age and experience are of course often closely related. On the other hand, there appears to be differences as regards the influence of age respectively experience

\footnotetext{
${ }^{7}$ According to ombudsmen at central LO.
} 
on employer and member related problems. The comparatively high representations of the young age/little experience groups in the personal problem category in the present data, and the increased tendency to report problems, can in part be explained as consequences of their being young and new to their assignment. The stress factor can further be explained by that these groups often have to combine work and union tasks with small children and family life. A third interpretation is that these groups have a different conception about what constitutes the essence of the union assignment, being more targeted towards the needs of members, which brings problem experiences, and feelings of frustration and distress when their abilities to fulfil them are perceived as insufficient. This in its turn, can be a reflection of recent years' changes in work place relations, including attempts to safeguard a fading membership. This interpretation was confirmed when talking to full-time union officers who stated that the union organisation is presently undergoing a transformation where individual membership and soft questions are to receive increased space, and that this change in direction is more easily adopted by the younger generation of shop stewards. On the other hand, the young age/ little experience group also frequently reported problems related to traditional work place disputes and an antagonistic relation to the employer.

Finally, some differences as regards union affiliate seem to be prevalent. Gender can be used to explain this deviation. However, organisational differences may also be considered. While the Transport workers' union often organise large work places (e.g., flight companies) with rights to negotiate, the Municipal workers' union is usually scattered over small workplaces where shop stewards work close to members. Negotiations often take place on another organisational level, at the union sections and departments.

\section{Summary and conclusions}

Previous research literature has described shop stewards' duties as extracting, involving multiple roles and tasks, and ranging from negotiations to reconciliation, dispute solving and work directed towards members. Member apathy, lack of authority and management treatment have further been described as commonly experienced problems (e.g., Reshef 1987; Schuller and Robertson, 1983). The result of this study implies that the situation of Swedish shop stewards do not deviate substantially from this picture, even though their conditions are somewhat different. On the contrary, all the categories from Rehefs' 1987 study was found in the Swedish sample, and they are also in line with the findings of Poole (1974) concerning shop stewards' major duties. An 
exception is the decreased involvement of local shop stewards in negotiations put forward by Terry (1995). Traditional work disputes and a hostile relationship with the employer by far made up for the largest problem category. Here, the Swedish unions' significant, accentuated reliance on the workplace level for certain functions may pose extra pressure on the individual shop steward.

The result of this study is also much in line with the previous research on union work under changing conditions. It restates Pupo and White's (1994) conception of its stable fundamental components, and simultaneously supports Rigby and Smythe's (1999) ideas about an increasing awareness of the need to respond to membership needs. On the other hand, it rejects their claim of a replacement of union-management opposition with collaboration, probably reflecting the specific Swedish circumstances with a strong local level frequently involved in workplace disputes. Further, the results indicate differences with regard to union affiliate, gender, age and experience. A conclusion then would be that basic union work characteristics remain the same in spite of national belonging and changing union conditions, but that new perspectives on the heterogeneity of unions are simultaneously emerging and taken in by new generations and groups of shop stewards. These perspectives need to be included when trying to facilitate the work of shop stewards.

\section{The shop steward-member relationship}

Skogstad (1997) summarises recent research on work role expectations and points out how role overload, i.e., numerous or excessive tasks and/or conflicts between work and family life, are stressors often associated with job dissatisfaction, tension and lack of confidence. As shown in the study, union work roles are demanding as regards being able to handle numerous tasks simultaneously. Further, they sometimes conflict with private life. When shop stewards feel that they do not have the time, support, or resources to satisfy the needs of members, this has far-reaching consequences for the unions. It has been claimed (Kelly, 1994) that individual participation in collective action is strongly correlated to identification with the union. Experience from Sweden implies that this identification is in decline (Sverke and Sjöberg, 1997). In a comprehensive survey undertaken by LO (Nelander and Lindgren, 1998), almost one out of three respondents stated that they were in doubt whether membership would bring them any benefit. The results support the claim that shop stewards play a significant part in the union movement and its contemporary challenges. When members were displeased with the performance of their union organisation, they often blame the shop stewards, and vice versa, leading to the situation where perceived shortcomings of the shop stewards can result in a rejection of the union as a whole. 


\section{Facilitating the work of shop stewards}

If shop stewards in the eyes of members embody the union organisation and if they simultaneously experience a complex work situation, it follows that they should be given much attention when dealing with the problems of unions. Especially in Sweden, where the local workplace organisation traditionally has had much responsibility (Kjellberg, 1983) and decentralisation is on the increase, corresponding support to shop stewards seems relevant. But given that union tasks and experienced problems do not seem to differ substantially as regards national diversity and change over time, support to shop stewards should likewise not differ significantly and experience could beneficially be shared across nations.

Supportive measures: A range of supportive measures could be taken in order to facilitate union work. For instance, programs for continuous education are essential for an improved union work situation. As regards LO, training provided to shop stewards is generally restricted to a basic level concentrating on elementary union facts, laws and agreements. But only about half the number of shop stewards receive even the basic training. ${ }^{8}$ As illustrated in the study, the union assignment includes a broad range of issues, comprising substantial demands on competence. Training for development of personal competence, e.g., leadership and conflict handling, should complement factoriented union courses.

Social support at work has repeatedly been shown to be associated with job satisfaction and well-being. In a research review (Dallner, 1997) it is emphasised how it can take on different forms, e.g., informational support and appraisal support. The need for cross-union support networks among safety shop stewards has already been noted by Frick (2000). From the data it is concluded that on many occasions shop stewards feel uncertainty and insufficiency. Increased access to the support from others of both an informational and appraisal kind would then be valuable, both hierarchically within and across the unions.

The study illustrates how both members and employers seem to have an insufficient or inadequate comprehension about the union assignment. Improved information to the latter parties, e.g., information campaigns, is a first step in removing this miscomprehension. Especially as regards members, more efficient and improved information is a must.

\footnotetext{
${ }^{8}$ According to ombudsmen at the Swedish LO, the lack of sufficiently trained shop stewards constitutes one of the organisation's major problems. Of approximately 225000 shop stewards, about 50 percent are estimated to have received basic training. Only about 10 percent get any further training.
} 
Information technology: When productivity growth, work place relations, unions and unionisation are discussed, the crucial role of information and communication has often been pointed out (Klay and Chen, 1993; Mori, 1991; Kersley, 1997). Nevertheless, potential benefits of using information technology as a tool within the union movement have not received wider attention within research (for a few exceptions see, for example, Solomon, 1992). Neither are an extensive use or explicit strategies from within the unions themselves the case (Pilemalm et al., 1998; Extejt, 1996). In fact, here the Swedish movement is rather progressive compared to other countries, having initiated information technology projects and strategies (Utbult, 1997; Pilemalm et al., 1998).

All the aforementioned suggestions address issues which have to do with present experienced insufficiencies and lack of resources in the union organisation. These are issues that in part can be supported by information technology. For instance, Frick (2000) argues for the need for the increased volume of union training. He also claims that the knowledge the unions provide must be more targeted towards the individual. Distance learning may be used to increase flexibility and efficiency; thereby training reaches more shop stewards and new groups will be able to participate, and it becomes more oriented towards the individual shop stewards' needs as classroom lectures are complemented. A combination of actual seminars and regular follow-ups over the Internet is a future potential option.

Information technology may be used further to form mentor and support networks among shop stewards, e.g., by the formation of e-mail lists and creation of discussion forums and electronic bulletin boards. Also here, support can be individually targeted, for instance reflecting the differences found as regards gender, affiliates and age/experience. As to exchange of information between shop stewards and members, Kjellberg (1997) has suggested that new meeting forms and more direct democracy are needed to improve the mutual understanding between the parties. Here, for instance bulletin boards, discussion forums, and videoconference systems may be used. In general, it is crucial that possible implementations of technology take the actual needs of users, i.e., shop stewards and other potential stakeholders, into account. The study can serve as a starting-point for identifying such needs.

\section{Future research}

From the study, it can be inferred that shop stewards and their work play an important role when confronting challenges to the unions. However, further knowledge has to be acquired. For instance, this article examined shop stewards' perception of their situation and construction of reality. Concentrating 
exclusively on them automatically involves the risk of only capturing half the picture. Misunderstanding or misconstrual of the other part's intentions is a major exacerbation factor as regards conflicts. It has been shown (Robinson and Friedman, 1995) that unions tend to underestimate the goodwill of employers in negotiations and concern for their workers, as well as employers simultaneously overestimate the militancy and unreasonableness of unions. Conducting an inquiry among employers and members might reveal a partly different picture. Accordingly, the perspectives of the latter parties should also be taken into account before establishing a balanced problem picture. In addition, further analysis of shop stewards' problems is needed, not the least how they deal with the problems.

Also, differences related to the quantitative distribution of problem among respondent categories were based on a small sample and should be seen as indicative rather than as absolute tendencies. These indications need to be tested on a larger material. Finally, even though the fundamental components of union work seem to be fairly stable, internal structures and institutional characteristics of individual union affiliates should be looked into. By identifying similarities, differences and target groups, potential support might be more beneficial.

\section{Acknowledgements}

The authors wish to thank Gunnela Westlander, Ove Ivarsen and Henrik Eriksson for providing useful comments on this article. This research has been financed by the Swedish Board for Development of Competence (KKstiftelsen).

\section{References}

Addison, J. T. and Siebert, S. (1998). Union Security in Britain. Journal of Labor Research, 19(3), 495-516.

Aryee, S. and Debrah, Y.A. (1997). Members' Participation in the Union: an Investigation of some Determinants in Singapore. Human Relations, 50(2), 129147.

Batstone, E., Boraston, I. and Frenkel, S. (1977). Shop Stewards in Action. The Organization of Workplace Conflict and Accommodation. Oxford: Basil Blackwell. 
Bognanno, M. F. and Kleiner, M.M. (1992). Introduction: Labor Market Institutions and the Future Role of Unions. Industrial Relations, 31(1), 1-12.

Bradley, C. (1992). Turning Anecdotes into Data - the Critical Incident Technique. Family Practice, 9(1), 98-103.

Cheek, J., O’Brien, B., Ballantyne, A. and Pincombe, J. (1997). Using Critical Incident Technique to Inform Aged and Extended Care Nursing. Western Journal of Nursing Research, 19(5), 667-682.

Clack, G. B. (1999). Gender Differences in Medical Graduates Assessments' of their Personal Attributes. Medical Education, 33(2), 101-105.

Clark, P. F., Gilbert, K., Gray, L. S. and Solomon, N. (1998). Union Administrative Practices: a Comparative Analysis. Journal of Labor Research, 19(1), 189-201.

Crain, M. (1994). Gender and Union Organizing. Industrial and Labor Relations Review, 47(2), 227-248.

Dallner, M. (1997), Social Support. In K. Lindström (Ed.), Review of Psychological and Social factors at Work and Suggestions for the General Nordic Questionnaire. Copenhagen: Nordic Council of Ministers.

Darlington R. (1994). Shop Stewards' Organisation in Ford Halerwood: from Beynon to Today. Industrial Relations Journal, 25(2), 136-149.

Dean, P. J. (1998). A Qualitative Method of Assessment and Analysis for Changing the Organizational Culture. Performance Improvement, 37(2), 14-23.

Edwards, P. K. (1992). Conflict at Work. A Materialist Analysis of Workplace Relations. Oxford: Basil Blackwell.

Ehn, P. and Kyng, M. (1987). The Collective Resource Approach to Systems Design. In P. Ehn, M. Kyng and G. Bjerknes (Eds.), Computers and Democracy. Aldershot: Avebury. 
Extejt, M. M. and Lynn, M. P. (1996). Trends in Computer Use in Collective Bargaining. Information \& Management, 30(3), 111-117.

Fisher E. G and Reshef, Y. (1992). Shop Steward Performance - a ConstrainedDecision Analysis. Relations Industrielles-Industrial Relations, 47(1), 25-41.

Flanagan, J. C. (1954). The Critical Incident Technique. Mental Bulletin, 51, 327-358.

Frick, K. and Walters, D. (1998). Worker Representation on Health and Safety in Small Enterprises: Lessons from a Swedish Approach. International Labor Review, 137(3), 1-20.

Frick, K. (2000). Bättre möjligheter till en bättre arbetsmiljö. Om skyddsombudens informations- och kunskapsförsörjning. Behov - möjligheter tillgång - utbud [Better Possibilities for an Improved Work Situation. About the Information and Knowledge Support for Safety Representatives. Needs Possibilities - Access - Demand]. Work report. Arbetstagarkonsult AB.

Gardell, B. and Westlander, G. (1968). Om industriaarbete och mental hälsa [About Industrial Work and Mental Health]. Ph.d. Thesis. Stockholm: Personaladministrativa rådet.

Gwartneygibbs, P. A. and Lach, D.H. (1994). Gender Differences in Clerical Workers' Disputes over Tasks, Interpersonal Treatment and Emotion. Human Relations, 47(6), 611-639.

Hultåker, Ö. E. (1977). Models of Job Satisfaction. Ph.d. Thesis. Uppsala University.

Kanter, R. (1977). Men and Women of the Corporation. New York: Basic Inc.

Kearsley, B. and Martin, C. (1997). Productivity Growth, Participation and Communication. Scottish Journal of Political Economy, 44(5), 485-501.

Kelly, C. and Kelly, J. (1994). Who Gets Involved in Collective Action?: Social Psychological Determinants of Individual Participation in Trade Unions. Human 
Relations, 47(1), 63-88.

Kjellberg, A. (2000). Facklig organisering och arbetsmarknad: marginalisering av ungdomar och invandrare? [Unionisation and Labor Market: Marginalisation of Young People and Immigrants?], In S. Tegle (Ed.), Har den svenska modellen överlevt krisen? Utvecklingstendenser $i$ arbetslivet inför 2000-talet [Has the Swedish Model Survived the Crisis? Development Tendencies for the 21th Century]. The Swedish National Institute for Working Life.

Kjellberg, A. (1998). Sweden: Restoring the Model? In A. Ferner and R. Hyman (Eds.), Changing Industrial Relations in Europe. Oxford: Blackwell.

Kjellberg, A. (1997). Fackliga organisationer och medlemmar i dagens Sverige [Union Organisations and Members in Contemporary Sweden]. Lund: Arkiv.

Kjellberg, A. (1983). Facklig organisering i tolv länder [Unionisation in Twelve Countries]. Ph. d.Thesis. Lund: Arkiv.

Klay, W. E. and Chen, F. F. (1993). Public Employee Perceptions of Unions as Intercessors for Technological Change. Journal of Collective Negotiations, 22(4), 341-350.

Lecher, W. (Ed.) (1994). Trade Unions in the European Union. A Handbook. London: Lawrence and Wishart.

Mellor, S. (1995). Gender Composition and Gender Representation in Local Unions - Relationships between Women's Participation in Local Office and Women's Participation in Local Activities. Journal of Applied Psychology, 80(6), 706-720.

Mori, P. A. (1991). On Incomplete Information and the Emergence of Trade Unions. In G. Ricci (Ed.), Decision Processes in Economics. Berlin: SpringerVer Cop.

Nelander, S. and Lindgren, V. (1998). Röster om facket och jobbet. Synen på fackligtmedlemsskap och fackets uppgifter [Voices on the Union and Work. The View on Union Membership and Union Assignments]. LO-Report No.1, Department for Payment and Work.

Norman, I. J., Redfern, S. J., Tomalin, D. A. and Oliver, S. (1992). Developing Flanagan's Critical Incident Technique to Elicit Indicators of High and Low 
Quality Nursing Care from Patients and their Nurses. Journal of Advanced Nursing, 17, 590-600.

Pilemalm S., Hallberg, N. and Timpka, T. (1998). From 'the good work' to 'the good life: a Perspective on Labor Union Visions Regarding Information Technology. Proceedings of the Fifth Biennial Participatory Design Conference, Seattle, WA, CPSR, 137-145.

Pilemalm, S., Hallberg, N. and Timpka, T. (2001). Organisational Policy and Shop-Floor Requests in Design. Visualisation of the Argumentation behind an Information System for the Swedish Trade Union Movement, Scandinavian Journal of Information Systems, 13, 7-30.

Poole, M. (1974). Towards a Sociology of Shop Stewards. The Sociological Review, 22(1), 57-82.

Pupo, N. and White, J. (1994). Union Leaders and the Economic Crisis: Responses to Restructuring. Relations Industrielles - Industrial Relations, 49(4), $821-45$.

Reshef Y. (1987). A Typology of Shop Stewards - a Confirmatory FactorAnalysis. Relations Industrielles-Industrial Relations, 42(1), 150-167.

Reynolds, M. O. (1998). The Prospects for Right to Work. Journal of Labor Research, 19(3), 519-528.

Rheaume, J., St Jean, M. and Maranda, M. (1998). Changements dans le milieu de travail et dans les syndicats: les leaders syndicaux vivent de la detresse [Changes in Workplaces and Unions: Union Leaders Living in Distress]. International Sociological Association (ISA).

Rigby, M. and Smith, R. (1999). Union Responses in Electronics: a Globalised Environment. Industrial Relations Journal, 30(1), 2-15.

Robinson, R. J. and Friedman, R. A. (1995). Mistrust and Misconstrual in Union-Management Relationships: Casual Accounts in Adversarial Contexts. The International Journal of Conflict Management, 6(3), 312-327. 
Sandberg, A.., Broms, G., Grip, A., Steen, J. and Ullmark, P. (1992). Technological Change and Co-Determination in Sweden. Philadelphia: Temple University Press.

Schuller, T. and Robertson, D. (1983). How Shop Stewards Allocate Their Time: Shop Steward Activity and Membership Contact. British Journal of Industrial Relations, 21, 330-342.

Skogstad, A. (1997). Role Expectations. In K. Lindström (Ed.), Review of Psychological and Social factors at Work and Suggestions for the General Nordic Questionnaire. Copenhagen: Nordic Council of Ministers.

Solomon, N. and Templer, A. (1992). Factors Determining the Successful Implementation of New Information Technology in a Professional Union. Industrial Relations, 47(2), 325-332.

Sverke, M. and Sjöberg, A. (1997). Ideological and Instrumental Union Commitment. In M. Sverke (Ed.), The Future of Trade Unionism. International Perspectives on Emerging Union Structures. Aldershot: Ashgate.

Terry, M. (1995). Trade Unions: Shop Stewards and the Workplace. In P. Edwards (Ed.), Industrial Relations: Theory and Practice. Blackwell: Oxford.

Utbult, M. (1997). LO-medlemmarna och informationstekniken. Rapport från LOs IT-projekt [The LO Members and Information Technology. Report from LO's IT-Project]. Stockholm: Brevskolan.

Viswesvaran, C. and Desphande, S. P. (1998). Unionization Decision of Members and Non-Members of an Employee Association. Journal of Labor Research, 19(3), 561-569.

Walters, D. and Frick, K. (2000). Worker Participation and the Management of Occupational Health and Safety: Reinforcing or Conflicting strategies? In K. Frick et al (Eds.), Systematic Occupational Health and Safety Management: Perspectives on an International Development. Oxford: Elsevier. 
How do Shop Stewards Perceive their Situation and Tasks?

Preconditions for Support of Union Work 